\title{
Psychopatie, empatie a morálka
}

\section{Psychopathy, Empathy and Morality}

\author{
Petra Chudárková* \\ Katedra filozofie, Filozofická fakulta, Univerzita Palackého v Olomouci
}

\begin{abstract}
Abstrakt
Psychopatie je v českém prostředí stále ještě termínem, kterému se odborníci z určitých důvodů spíše vyhýbají. Tento př́istup má však své důsledky. Protože chybí adekvátní diagnostická metoda, není český systém schopný se s psychopatickými jedinci uspokojivě vypořádat. Jelikož psychopati představují pro společnost skutečné riziko, cílem předkládaného textu je ukázat, proč by měla být i v českém prostředí psychopatie považována za jednu z poruch osobnosti a proč by měla být diagnostikována. Článek bude sestávat ze čtyř částí vycházejících z poznatků současné psychologie a neurální vědy. Jelikož jsou psychopati často popisováni jako osoby bez empatie, bude první část věnována právě jí. Následující oddíl se zaměří na psychopatii, mimo jiné i s ohledem k tématu empatie, a také detailněji vysvětlí důvody jejího opomíjení v českém prostředí. Třetí část se bude zabývat etickými otázkami spojenými s problematikou psychopatie a omezenou schopností empatie, především morálním poznáním, motivací a odpovědností. Poslední část představí praktické důsledky týkající se trestněprávní oblasti, ale také možností léčby.
\end{abstract}

Klíčová slova: psychopatie, empatie, morálka, morální motivace, odpovědnost.

\begin{abstract}
In the Czech Republic, specialists still tend to avoid the term ,psychopathy' for several reasons. Psychopathy is not recognized in current Diagnostic and Statistical Manual of Mental Disorders (DSM-5), nor in the International Classification of Diseases and Related Health Problems (ICD; MKN-10 in Czech). Moreover, the term ,psychopathy itself is controversial because it is considered to be pejorative by many specialists. Usually, individuals with psychopathic traits are diagnosed either with antisocial personality disorder, or dissocial personality disorder. Nevertheless, in the last thirty years, there has been enormous growth of psychological and neuroscientific research concerning psychopathy, especially in Northern America and Western Europe. The most commonly used tool for assessment of psychopathic individuals has been the Hare Psychopathy Checklist - Revised (PCL-R). Its latest version uses a four-factor model which reflects interpersonal, affective, behavioural, and antisocial characteristics of psychopathy. Probably the greatest advantage
\end{abstract}

\footnotetext{
* Korespondenční autorka: Petra Chudárková, Katedra filozofie, Filozofická fakulta, Univerzita Palackého v Olomouci, Křřžkovského 12, 77180 Olomouc, Česká republika.

Email: petra.chudarkova01@upol.cz
} 
of Hare's newest Checklist is that it captures specific features of psychopathy which allows to distinguish it from the aforementioned diagnoses, i.e., antisocial and dissocial personality disorders. Moreover, the checklist is able to predict, with high accuracy, the probability of recidivism of previously incarcerated individuals. Psychopathic individuals are more than four times as likely to re-offend and therefore may pose a serious threat to society. Unfortunately, in the Czech Republic this matter has been virtually overlooked. However, there are practical consequences of this approach. Czech system is not able to cope with psychopathic individuals in a satisfactory way, as proper diagnostic method is missing. For psychopaths pose a serious threat to society, the aim of this paper is to show why it is important to consider psychopathy as one of personality disorders and why it is necessary to diagnose it. The paper consists of four parts based on recent psychological and neuroscientific research. First part is devoted to empathy, as psychopaths are often described as individuals lacking it. This part explains what empathy is, what its evolutionary origin is, how it develops during one's life, and how it helps to promote moral behaviour. Second part focuses on psychopathy itself, also with regard to problem of empathy. First, there is a clarification of why attention has not been paid to the issue of psychopathy in the Czech Republic. Then this section describes main psychopathic traits, how male and female psychopathy differs, what the psychological and neurological differences between the so called successful and unsuccessful psychopathic individuals are, and what cognitive moral deficits psychopaths suffer from. It also describes previous versions of PCL-R, and their advantages and disadvantages. Third part discusses ethical issues concerning psychopathy and reduced empathy, mainly moral knowledge, motivation, and responsibility. Last part presents practical implications regarding especially criminal law and potential treatment.

Keywords: psychopathy, empathy, morality, moral motivation, responsibility.

\section{Úvod}

Psychopatie je tématem, kterému je v zahraniční literatuře věnována značná pozornost, a to především v rámci psychologického a neurálního výzkumu. V české odborné literatuře je naneštěstí tato problematika až na pár výjimek spíše opomíjena. ${ }^{1}$ Jedinci, u kterých je psychopatie diagnostikována, bývají mnohdy označováni jako amoralisté (amoralist), tedy jako osoby postrádající motivaci k morálně správnému jednání (Nichols, 2002; Bedke, 2009). ${ }^{2} \mathrm{Z}$ toho důvodu představují důležitý etický problém, se kterým je třeba se vyrovnat. Neschopnost morálního jednání bývá u psychopatů často vysvětlována nedostatkem empatie. Ani jedna z uvedených představ však není zcela přesná.

Předkládaný článek sestává ze čtyř částí. První část je věnována empatii. Vysvětluje, jakým způsobem se empatie liší od jí podobných fenoménů, jaký je její evoluční původ, jak se vyvíjí v průběhu lidského života a jak přispívá k lidskému morálnímu jednání. Následující oddíl se

\footnotetext{
${ }^{1} Z$ českých publikací věnujících se čistě psychopatii lze zmínit pouze popularizační knihu Čas psychopatů od bratrů Honzákových (Honzák \& Honzák, 2018). Z překladů ale stojí rozhodně za zmínku Moudrost psychopatů (Dutton, 2013), Psychopatův průvodce na cestě k úspěchu (McNab \& Dutton, 2015) a po dlouhých dvaadvaceti letech přeložená publikace Bez svědomí: znepokojivý svět psychopatů mezi námi (Hare \& Gust, 2015). O narůstajícím zájmu o tuto tématiku svědčí také dva ročníky České konference o psychopatii $(2017,2018)$.

${ }^{2}$ Termín ,amoralism“ bývá v etice chápán i silněji jako naprostý nezájem o morálku (Schramme, 2014).
} 
zaměřuje na psychopatii, mimo jiné i s ohledem k tématu empatie. Objasňuje, v čem psychopatie spočivá, proč o ní není v českém prostředí př́lišs slyšet, a popisuje deficity, které psychopatičtí jedinci v porovnání s ostatními vykazují v oblasti morálního usuzování a jednání. Třetí část se zabývá etickými otázkami spojenými s problematikou psychopatie a omezenou schopností empatie, především morálním poznáním, motivací a odpovědností. Poslední část představuje praktické důsledky týkající se trestněprávní oblasti, ale také možností léčby. Cílem je ukázat, že psychopatie by neměla být v českém prostředí opomíjena, a to především z důvodu nebezpečí, které někteří psychopatičtí jedinci pro společnost představují.

\section{Empatie}

Empatie je pro morální usuzování a jednání v mnoha ohledech nepostradatelná. Nejčastěji bývá chápána jako přiměřená emoční reakce na situaci a emoce druhých či jako schopnost těmto pocitům rozumět a sdílet je (Decety, Michalska, \& Kinzler, 2011; de Vignemont \& Singer, 2006; Lamm, Batson, \& Decety, 2007). Takové vymezení však neumožňuje odlišit empatii od některých př́buzných fenoménů, jako je zaujetí perspektivy, sympatie či emoční nákaza (srov. Mikoška \& Novák, 2017). Jako poměrně nápomocná se v tomto ohledu jeví užší definice, která empatii definuje jako stav, kdy jsou v jedinci na základě představy či přímého pozorování emocí u druhých vyvolány totožné afekty a kdy si je jedinec zároveň vědom toho, že zdrojem těchto afektů je druhá osoba (de Vignemont \& Singer, 2006).

Empatie přspívá velkou měrou ke zvýšení naší biologické zdatnosti. Původně zřejmě sloužila jako mechanismus zajišt’ující péči o potomstvo a až postupem času se, pravděpodobně jako adaptace, vyvinula k usnadnění interakce a kooperace jak mezi biologicky nespř́zněnými členy skupiny, tak i mezi př́slušníky jiných druhů (Decety, 2014) Dalšími výhodami, které nám poskytuje, jsou schopnost lepšího utlumení vlastní agrese, předvídání reakcí a chování druhých a získávání informací o okolí (de Vignemont \& Singer, 2006). Její vývoj je úzce svázán se vznikem vyšších kognitivních funkcí - jazyka, řídících funkcí a teorie mysli - jež mají sídlo v prefrontálním kortexu a jsou navrstveny na fylogeneticky starší emocionální a sociální kapacity (Decety, 2014). Empatii lze rozložit na tři základní složky, z nich každá má jinou vývojovou dráhu. Jsou jimi afektivní nabuzení a chápání emocí, které jsou afektivními komponenty empatie, a emoční regulace, která je kognitivním komponentem (Decety, 2010). Každá z nich se v průběhu lidského života vyvíjí odlišně, do značné míry jsou však na sobě závislé.

Složkou, která se vyvíjí nedříve a pracuje rychle a zcela automaticky, je afektivní nabuzení, které vzniklo jako reakce na př́ijemné a nepříjemné podněty a slouží také k rozpoznávání přátelských a nepřátelských stimulů. K jeho rozvoji dochází velmi brzy - již okolo tří až sedmi dnů dokáží novorozenci rozpoznat negativní emoce z tónu hlasu a zároveň rozlišit vlastní a cizí pláč, což někdy bývá považováno za jednu z nejranějších forem empatie (Decety, 2014). Od přibližně desátého týdne jsou novorozenci schopni napodobovat výrazy strachu, smutku či překvapení. Afektivní nabuzení hraje důležitou roli ve vývoji morální citlivosti (Decety et al., 2011) a usnadňuje sociální učení, samo o sobě však pro empatii není dostačující, jelikož v tomto období si ještě jedinci nedokáží vytvořit reprezentaci druhých osob jako jednajících agentů s vlastními, a většinou odlišnými intencemi. Jedná se tedy často spíše o napodobování výrazů druhých či o emoční nákazu. Klíčovými mozkovými oblastmi zprostředkovávajícími afektivní nabuzení 
jsou amygdala zpracovávající projevy strachu a bolesti, hypothalamus, jenž je nezbytný pro parentální chování a starost o druhé, hipokampus a orbitofrontální kortex, který je spojován s citlivostí k odměnám a trestům a umožňuje plánování a regulaci vlastního chování (Decety, 2014)

Dalším vývojovým stupněm je chápání emocí, kterého je dítě plně schopno většinou až mezi druhým a třetím rokem. Je to $\mathrm{z}$ toho důvodu, že přibližně v té samé době dochází k rozvoji teorie mysli, což dítěti umožňuje vzít v úvahu nejen svou, ale i cizí perspektivu a díky tomu odlišit záměry a pocity druhých od svých vlastních. Teorie mysli je však zcela vyvinuta až v pozdní adolescenci, kdy dochází k ukončení vývoje mediálního prefrontálního kortexu. Přibližně ve věku čtyř let již dítě chápe, že emoce druhých závisí na způsobu jejich vnímání dané události a také na jejich přáních či očekáváních, která se této události týkají. Čím je dítě starší, tím lépe dokáže zpracovávat složitější informace, mezi které patří i intence a přesvědčení druhých, a také komplexnější sociální emoce jako jsou pýcha, stud, rozpaky či žárlivost (de Vignemont \& Singer, 2006). Za zpracování těchto podnětů je nejvíce odpovědný ventromediální prefrontální kortex.

Nejpozději jedinci dosahují schopnosti emoční regulace, která spočívá ve vyhodnocování a přehodnocování vlastních emocí takovým způsobem, aby byly společensky přijatelné. První přiznaky sebekontroly lze pozorovat u kojenců v době okolo tří měsíců, ve věku jednoho roku je již kontrola účelovější a slouží k usnadnění interakce s blízkými (Kopp \& Neufeld, 2003). Zajímavé je, že děti, které se o seberegulaci snaží více, vykazují také vyšší míru empatického zájmu a sympatie. Míra emoční kontroly vzrůstá s osvojováním jazyka a schopností své emoce verbalizovat. Její vývoj trvá až do pozdní adolescence a překrývá se s plným vyvinutím řídících funkcí a metakognice, díky níž jsme schopni sebereflexe. Pro způsob, jakým své emoce dokážeme „ukočírovat“, jsou však klíčové i naše cíle, záměry, motivace a celkový kontext situace. Na správném fungování emoční regulace se podílí dorzolaterální prefrontální kortex, přední cingulární kortex, ventromediální prefrontální kortex a amygdala, jejíž propojení s prefrontálními oblastmi je pro schopnost empatie zásadní (Decety, 2010).

Podstatné je, že jak míra aktivace, tak funkční propojení jednotlivých mozkových oblastí se v různých věkových obdobích liší, což se projevuje v rozdílných reakcích na některé situace v průběhu našeho života. Tak lze vysvětlit například vyšší citlivost dětí k ublížení druhým - čím mladší jedinec je, tím vyšší vykazuje aktivaci v amygdale, která společně s orbitofrontálním kortexem analyzuje afektivní význam stimulu (Decety, Michalska, \& Kinzler, 2012). Oblasti prefrontálního kortexu, které se vyvíjejí později, stojí za naší citlivostí k sociálním normám. Jejich vyvíjející se propojení s amygdalou určuje způsob, jakým si dokážeme morální normy osvojit, a umožňuje nám být více selektivní ve výběru vhodné reakce (Decety et al., 2011). Deficit v tomto propojení se negativně projevuje v míře empatie a prosociálním chování (Shenhav \& Greene, 2014), což lze nejlépe pozorovat u psychopatie. Podstatnou mozkovou oblastí pro empatii je také insula, která zpracovává vlastní tělesné reakce jako např́klad tlukot srdce či teplotní vjemy a díky jejichž mentálním reprezentacím nám následně pomáhá předvídat afektivní stavy druhých. Lidé, u nichž je diagnostikována alexithymie, ${ }^{3}$ mají problém své emoce vyjadřovat, v důsledku čehož trpí také sníženou schopností empatického vcítění (Klimecki \& Singer, 2013). Insula společně s předním cingulárním kortexem citlivě reaguje při zakoušení či představě fyzické bolesti, sociálního distresu či extrémního smutku. Schopnost empatie a prosociálního chování však závisí i na hladině některých hormonů, především oxytocinu a vasopresinu (Decety, 2014; Tabak et al., 2015). Klíčové je, že všechny z výše uvedených složek uskuteč-

\footnotetext{
${ }^{3}$ Ke korelaci psychopatie a alexithymie viz Jonason a Krause (2013).
} 
ňovány danými mozkovými oblastmi jsou nezbytné pro správné fungování empatie. Oslabení jen některé z nich může mít pro morální život jedince fatální důsledky, což lze vidět právě na prrípadu psychopatie.

\section{Psychopatie}

Psychopatie je poruchou osobnosti, o které je v českém prostředí slyšet v posledních letech čím dál častěji, a to především v popularizační literatuře a neodborných časopisech. V odborném prostředí však v porovnání se zahraničím bývá tento termín používán stále jen zřídka, a to ze dvou hlavních důvodů. Kvůli svému užívání v minulosti představuje termín ,psychopat“ pro mnohé odborníky stále ještě pejorativní pojem, kterému by bylo lepší se vyhnout a namísto něj používat přijatelnější označení „disociální porucha“4 (Křížová, 2016). Druhým důvodem, proč se s tímto termínem nesetkáváme často, je, že psychopatie bývá směšována s antisociální poruchou (Honzák \& Honzák, 2018). Občas jsou také jako psychopati obecně označováni jedinci, kteři postrádají schopnost empatie (Koukolík \& Drtilová, 2006; Koukolík, 2016). Ani jedna z uvedených charakteristik však není zcela správná. Velmi zjednodušeně řečeno, antisociální porucha osobnosti se vyznačuje antisociálním chováním, které je mnohdy, nikoliv však nutně, typické i pro psychopaty. Zároveň se ukazuje, že psychopati mají schopnost empatie pouze omezenou, nikoliv zcela absentující.

Cílem následujících řádků proto bude na základě současných psychologických a neuroetických zahraničních studií co nejlépe vysvětlit, jak je psychopatie - chápaná bez jakéhokoliv pejorativního obsahu - diagnostikována, jaké jsou její charakteristické rysy, jak se liší od antisociální poruchy, jaké jsou rozdíly mezi mužskou a ženskou psychopatií a které složky empatie jsou u psychopatických jedinců oslabeny. ${ }^{5}$ Záměrem není pouze přiblížit českému čtenáři zahraniční výzkum, ale především uchopit $\mathrm{v}$ nezjednodušené podobě ty rysy psychopatie, které mají zásadní důsledky pro oblast morálky a které bývají občas přehlíženy či příliš zjednodušovány. ${ }^{6}$

V současnosti se stupeň psychopatie nejčastěji hodnotí na základě dotazníku Psychopathy Checklist - Revised (PCL-R), který existuje v několika variantách ${ }^{7}$ a jehož autorem je kanadský psycholog Richard Hare (Hare, Hart, \& Harpur, 1991). Dotazník sestává z dvaceti položek hodnocených na tříbodové stupnici od 0 do $2 \mathrm{v}$ závislosti na tom, nakolik daná položka odpovídá hodnocenému jedinci. $\mathrm{K}$ určení psychopatie se většinou užívá hranice třiceti bodů a více (Hare \& Neumann, 2006). ${ }^{8}$ Ve starších studiích pracoval Hare se svými kolegy s dvoufaktorovým hodnocením (Hare et al., 1991). První faktor se týká osobnostních a afektivních rysů jedince, jako sebestřednost, neschopnost pocit’ovat lítost, úzkost a některé další emoce či omezená schopnost empatie. Tyto rysy často korelují s psychopatií, machiavellismem a nar-

\footnotetext{
${ }^{4}$ Disociální porucha osobnosti (F60.2) podle MKN-10.

${ }^{5} \mathrm{Z}$ důvodu omezeného prostoru se článek nebude zabývat otázkou původu psychopatie. Současná evidence poukazuje jak na vliv genů, tak na možný negativní dopad prostředí, v němž daný jedinec žije. Pro přehled viz Anderson a Kiehl (2014).

${ }^{6}$ Mým záměrem je věnovat se pouze psychopatii u dospělých jedinců. V posledních letech se však soustředí čím dál tím větši část výzkumu i na psychopatii u dětí a adolescentů. Pro přehled o této tématice viz Farrington (2005). ${ }^{7}$ Dalšími verzemi jsou Psychopathy Checklist: Screening Version (PCL:SV) a Psychopathy Checklist: Youth Version (PCL:YV).

${ }^{8}$ Tato hranice se užívá především v Severní Americe, např́ílad v Británii je kritériem pouze dvacet pět bodů.
} 
cismem, které bývají souhrnně označovány jako temná triáda osobnosti (Paulhus \& Williams, 2002). Druhý faktor postihuje právě antisociální stránku psychopatie, tedy impulsivní chování vedoucí k porušování norem a nestabilní životní styl, kvůli kterým se jedinec nezřídka dopouští kriminálního jednání. Např́klad Cooke a Michie (2001) však považují dvoufaktorové schéma za př́liš zjednodušující, protože nerozlišuje, která ze složek tvoří jádro psychopatie, a která s ní pouze koreluje. Navrhují proto schéma trojfaktorové, které rozlišuje arogantní a nečestný způsob života, omezenou emocionální stránku a impulsivní a nezodpovědné jednání. Důraz je přitom kladen na osobnostní rysy, nikoliv na chování. Kriminální jednání nepovažují za součást, ale pouze za korelát či důsledek psychopatie (Cooke \& Michie, 2001).

Ačkoliv lze trojfaktorové schéma považovat za pokrok, podle Hara při bližší analýze také neobstojí (Hare \& Neumann, 2006). Evidence nejvíce nahrává čtyřfaktorovému schématu, které postihuje interpersonální, afektivní a antisociální aspekt psychopatie a životní styl. Interpersonální faktor se zaměřuje na povrchnost, sebestřednost, patologické lhaní a manipulativnost. Afektivní faktor obsahuje nedostatek lítosti či viny, emocionální plochost, omezenou empatii a neschopnost přijmout odpovědnost za své jednání. Antisociální aspekt hodnotí nedostatečnou kontrolu vlastního jednání, problematické jednání v mládí, mladistvou delikvenci, zrušení podmínečného propuštění a kriminální všestrannost jedince. V otázce životního stylu se jedná o vyhledávání stimulace, impulzivnost, nezodpovědnost, parasitický životní styl a nedostatek realistických cílů (Hare, 2003; Hare \& Neumann, 2006). Lze shrnout, že na rozdíl od antisociální poruchy se psychopatie primárně netýká jednání, ale osobnostních rysů, ačkoliv antisociální chování je většinou považováno za její součást (Neumann, Hare, \& Newman, 2007). Kromě výše uvedených charakteristik lze zmínit ještě sklony k destrukci, promiskuitu, krátkodobé vztahy, aroganci či kouzlo osobnosti, které psychopatům umožňuje dosáhnout kýžených cílů (Dutton, 2013). Důležité je, že každý psychopat disponuje jinou kombinací a mírou uvedených vlastností, podle čehož se odvíjí stupeň psychopatie. $Z$ toho důvodu jsou někteří z těchto jedinců schopní v podstatě bez problémů fungovat $\mathrm{v}$ běžné společnosti, jiní se naopak mohou pravidelně dostávat do konfliktu se zákonem a představovat reálné riziko pro společnost.

Přestože je Harův dotazník pravděpodobně nejlepším existujícím nástrojem pro diagnostiku psychopatie, jeho přetrvávající nevýhodou je, že bohužel stále nedokáže zcela postihnout a odhalit všechny aspekty psychopatie (Neumann et al., 2007). Je také vytvořen spíše pro muže než pro ženy, u nichž jsou některé projevy psychopatie odlišné, ačkoliv poslední verze z roku 2003 dosáhla v tomto ohledu značného zlepšení (Hare, 2003; Hare \& Neumann, 2006). Tato diskrepance je způsobena pravděpodobně tím, že u žen není tak časté antisociální chování jako u mužů. ${ }^{9}$ Neužívají většinou fyzického násilí, ale jemnějších prostředků jako ostrakizmus, pomlouvání, narušování vztahů a podobně, s cílem vyvolat v oběti distres. Za oběti si vybírají někoho ze svého blízkého okolí, nezř́́dka se jedná o osoby, se kterými se nějakým způsobem identifikují - o partnera, dítě, kolegu či př́ítele. Také u nich chybí kouzlo osobnosti a přehnané sebevědomí, k úspěchu si pomáhají spíše flirtováním, které usnadňuje manipulaci s obětí. Typická je pro ně emoční nestabilita. Naproti tomu muži cílí spíše na své protivníky, jež považují za konkurenci. Bývají více agresivní a v důsledku toho se mnohdy dopouštějí kriminálních činů. I z toho důvodu je v souvislosti s psychopatií častěji slyšet o mužích než

\footnotetext{
${ }^{9}$ Jedno z možných vysvětlení této asymetrie poskytuje evoluční psychologie. Muži i ženy mají ve společnosti odlišné cíle, proto se i jejich strategie při snaze o jejich dosažení může lišit. Perspektivou evoluční teorie je také možné vysvětlit, proč psychopati ve společnosti vůbec existují (Glenn, Kurzban, \& Raine, 2011).
} 
o ženách. Obě skupiny však usilují o zisk a o vládu nad druhými (Forouzan \& Cooke, 2005; Logan \& Weizmann-Henelius, 2012; Wynn, Høiseth, \& Pettersen, 2012).

Klíčovou je u psychopatů omezená schopnost empatie. Nápomocné se zde jeví rozdělení empatie na tři typy, a to empatii kognitivní, která umožňuje utvoření reprezentace mentálního stavu druhé osoby, ${ }^{10}$ motorickou, jež spočívá v imitaci pohybů, a emoční, která slouží k vytvoření emocionální reakce na sociální projevy emocí. Kognitivní ani motorická empatie není u psychopatů zřejmě narušena, s výjimkou orbitofrontálního kortexu, jenž zprostředkovává reprezentace emočního stavu druhých. V př́ípadě emoční empatie je však situace složitější. Psychopati dokáží u jiné osoby správně zpracovat pozorovaný pocit znechucení a vzteku. Problematické je ovšem rozpoznání strachu a smutku z tónu hlasu a výrazu tváře, což je pravděpodobně způsobené narušením amygdaly. Oslabená je také schopnost zpracování bolesti druhých, za jejímž správným fungováním stojí insula a dorzomediální prefrontální kortex (Blair \& White, 2013; Decety, Chen, Harenski, \& Kiehl, 2013; Yoder, Keith, Harenski, Kiehl, \& Decety, 2015). Zajímavé je, že při představě vlastní bolesti reagují psychopaté stejně jako zdraví jedinci a vykazují normální až nadměrnou aktivaci v amygdale. Ovšem při představě bolesti druhých dochází k atypické aktivaci a propojení přední insuly a amygdaly s ventromediálním prefrontálním kortexem. Je také možné pozorovat odlišné spojení amygdaly a orbitofrontálního kortexu (Decety et al., 2013).

Skupinou, o které je v poslední době slyšet čím dál tím víc a jež je pravděpodobně početnější než běžní psychopati, jsou tak zvaní funkční či úspěšní psychopati. Jsou to jedinci, jejichž narušení není tak zásadní a umožňuje jim naprosto perfektně ve společnosti fungovat, často aniž by si jejich okolí čehokoliv všimlo. Vymezit definičně funkční psychopaty není úplně jednoduché, nicméně většinou se tyto osoby vyznačují vysokým stupněm psychopatie nebo alespoň některými psychopatickými rysy a - co je nejdůležitější - nebyli nikdy vězněni ani obviněni z jakéhokoliv zločinu. Patří k nim i sérioví vrazi, jimž se dlouho dobu dařilo unikat odhalení (Raine \& Glenn, 2014b). Vyskytují se ve všech vrstvách společnosti, nejvíce v profesích jako obchodníci, lékaři, politici, vědci, vojáci či právníci. Charakteristická je pro ně kromě jiného manipulativnost, egocentrismus, omezené emoční cítění, ale také kouzlo osobnosti, které zvyšuje jejich úspěšnost při dosahování zamýšlených cílů.

Oproti klasickým psychopatům vykazují funkční psychopati menší deficit ve struktuře a funkcích amygdaly a orbitofrontálního kortexu způsobujících problémy v emocionální oblasti. Naopak regiony spojované s kognitivními schopnostmi, především dorzolaterální prefrontální kortex (dlPFC), jsou nedotčené a některé jejich funkce mohou být dokonce posíleny, což těmto psychopatům umožňuje v porovnání se zdravými jedinci činit leckdy lepší rozhodnutí (Yang, Raine, Colletti, Toga, \& Narr, 2010). Jejich výhodou je také schopnost regulovat sklony k antisociálnímu chování a plánovat své jednání. Díky těmto rysům jsou často velmi úspěšní a dosahují vysokého sociálního postavení (Raine \& Glenn, 2014b). ${ }^{11}$

\footnotetext{
${ }^{10}$ Kognitivní empatie je v podstatě totožná s teorií mysli (Blair \& White, 2013).

${ }^{11}$ Několik př́ípadů úspěšných psychopatů lze nalézt i mezi prezidenty Spojených států. Ačkoliv tento závěr vychází z poněkud diskutabilní metody, jež spočívala ve vytvoření osobnostního profilu na základě způsobu vystupování zkoumaných politiků, výpovědí autorů jejich biografií a historických podkladů, ukázalo se, že úspěšné vykonávání úřadu bylo úzce spjato s omezenou schopností pocit'ovat strach a zároveň lepší regulací antisociálních tendencí. První tři místa obsadili Theodore Roosevelt, John F. Kennedy a Franklin D. Roosevelt. Bez zajímavosti není ani sedmé místo Williama Jeffersona Clintona (Lilienfeld et al., 2012).
} 


\section{Psychopati a morálka}

Poměrně běžně bývají psychopati označováni jako amorální, tedy jako jedinci, na jejichž chování nemají vliv obecně uznávané morální normy (Schramme, 2014). Pro celou řadu etických pozic představuje tato anomálie nevítanou výzvu, kterou je třeba nějakým způsobem do konceptu dané pozice zapracovat. Některým etikům však naopak slouží jako evidence podporující jejich vlastní stanovisko a podrývající opačnou pozici. V metaetice se v tomto ohledu hojně diskutuje několik vzájemně provázaných a na sobě závislých otázek. Jedná se o morální porozumění, morální poznání založené na schopnosti vytvoření si adekvátního morálního soudu, morální motivaci a morální odpovědnost u psychopatických jedinců. V oblasti normativní etiky pak přitahuje pozornost především tendence psychopatů volit v př́ípadě morálních dilemat protiintuitivní utilitaristické řešení, které je pro většinu běžných jedinců nepřijatelné (Bartels \& Pizarro, 2011; Koenigs, Kruepke, Zeier, \& Newman, 2012). Tento oddíl nemá ambici zabývat se zevrubně všemi uvedenými otázkami. Především ty spadající do metaetiky mají často spíše konceptuální obsah. Cílem proto bude zaměřit se hlavně na problém morálního poznání, motivace a odpovědnosti, a to pouze na tu jejich stránku, která má praktické důsledky a s jejímž rozhřešením může pomoci empirický výzkum.

Problém s psychopatickými jedinci vychází z velké části ze zjednodušené představy, podle níž si nedokáží vytvořit adekvátní morální soud, tedy správně zhodnotit danou morální situaci. Výzkumy však ukazují, že je tomu tak pouze částečně. Na základě starších výzkumů se zdálo, že zásadní rozdíl mezi psychopaty a běžnými jedinci spočívá ve schopnosti rozlišovat překročení morálních a konvenčních norem. Porušení obecně uznávaných morálních norem je u běžných jedinců doprovázeno negativními pocity (Blair, 1997). Naproti tomu konvenčně dané normy na naši emocionální stránku tak silně nepůsobí. Často jsou vázány na autoritu a pravidla a týkají se mimomorální oblasti. Porušení morálních norem bývá považováno za závažnější a na rozdíl od konvenčních norem je běžně zdůvodňováno s ohledem k blahu druhých (Smetana, Schlagman, \& Adams 1993; srov. Kelly, Stich, Haley, Eng, \& Fessler, 2007). Př́íkladem porušení morální normy může být odmítnutí pomoci jedinci, který trpí, př́ikladem porušení konvenční normy pak přecházení přechodu, když na semaforu svítí červená. Podle studií Blair (1995) a Blair, Jones, Clark a Smith (1995) postrádají psychopati negativní emoční reakci v př́ípadě morálních přestupků a nepřijatelnost morálních a konvenčních přestupů hodnotí identicky - oba typy považují za morálně nepřijatelné, ovšem zdůvodňují je nezávisle na ublížení osobě, které se daný čin dotýká, a nezávisle na autoritě. ${ }^{12}$ Někteř́ z těchto poznatků vyvozují důsledky pro schopnost morálního poznání a odpovědnost u psychopatů. Jestliže jsou tito jedinci schopní říct, že daný čin byl špatný, ale nechápou, proč byl morálně špatný, pak se lze domnívat, že jejich odpovědnost za vlastní jednání je kvưli omezené schopnosti morálního poznání přinejmenším oslabena (Levy, 2007). Zdá se však, že samotný design experimentů využívajících dělení na konvenční a morální přestupky je problematický, a proto jsou jejich poznatky v posledních letech zpochybňovány (Kelly et al., 2007; Aharoni, Sinnott-Armstrong, \& Kiehl, 2012).

\footnotetext{
${ }^{12}$ Toto na první pohled překvapivé zjištění zdůvodňují autoři možnou tendencí zkoumaných psychopatických jedinců upravit své odpovědi tak, aby je představovaly v lepším světle. Podrobná studie Aharoni, Sinnott-Armstrong a Kiehl (2012) však ukazuje, že při přísnějším nastavení podmínek experimentu dokáží psychopati v porovnání s kontrolní skupinou rozlišovat morální a konvenční přestupky podobně úspěšně.
} 
Studie využívající design morálních dilemat ukazují, že lidé s psychopatií racionálně chápou, že určitý čin je morálně špatný, a ví, že porušení zavedených norem bude mít následky, avšak je jim to tak říkajíc jedno. Na rozdíl od pacientů s poškozením ventromediálního prefrontálního kortexu (Ciaramelli, Muccioli, Làdavas, \& Pellegrino, 2007) např́íklad hodnotí i přes sníženou aktivitu v amygdale osobní a neosobní morální dilemata ${ }^{13}$ podobně jako zdraví jedinci (Cima, Tonnaer, \& Hauser, 2010). Tento poznatek ale možná platí jen pro některé psychopaty - z některých výzkumů vyplývá, že osoby s vyšším stupněm psychopatických rysů (Bartels \& Pizarro, 2011) a omezenější schopností pocit’ovat úzkost (Koenigs et al., 2012) vykazují větší ochotu volit v prŕípadě osobních morálních dilemat utilitaristické řešení.

Výše uvedené poznatky pomáhají uvést na pravou míru studie rozlišující posouzení přijatelnosti určitého jednání, tedy morální soud, a volbu potenciálního jednání v dané situaci. V př́ipadě závažných dilemat dokáží osoby se silnými psychopatickými rysy ohodnotit „chladnokrevné" utilitaristické řešení jako morálně neprrijatelné, ale na rozdíl od nepsychopatických jedinců by jej zároveň byly ochotné vykonat (Tassy, Deruelle, Mancini, Leistedt, \& Wicker, 2013). ${ }^{14}$ Původní domněnka, podle níž si jedinci s psychopatií nedokáží vytvořit kvůli chybějící, respektive oslabené emocionální reakci adekvátní morální soud, se tak zdá být chybná. Je pravděpodobnější, že ačkoliv psychopati postrádají tak silné negativní afekty jako běžní jedinci, dokáží si i přesto správný morální soud vytvořit, tedy disponovat morálním poznáním. ${ }^{15} \mathrm{Je}$ možné, že důvod, proč psychopati častěji jednají nemorálně, je, že v důsledku funkčního deficitu uvedených mozkových oblastí nejsou k morálnímu chování motivováni tak jako běžní jedinci. Na druhou stranu mohou být díky zvýšené funkci v pravém dorzolaterálním prefrontálním kortexu (dlPFC) schopni uvažovat více analyticky, což některým z nich umožňuje v zapeklitých situacích volit nevhodnější řešení16 (Cima, Tonnaer, \& Hauser, 2010; Glenn, Raine, Schug, Young, \& Hauser, 2009; Raine \& Glenn, 2014a).

\footnotetext{
${ }_{13}$ Dělení morálních dilemat na osobní a neosobní pochází ze studie Greene, Sommerville, Nystrom, Darley \& Cohen (2001). Greene rozlišoval scénáře, které měly v subjektech vyvolat silný rozpor a jemu odpovídající emocionální reakci, od těch, které vnitřní rozpor nevyvolávaly. V dilematech prvního typu se subjekty musely zpravidla rozhodnout, zda ublíží jedinci či jej obětují ve prospěch skupiny, a to za použití fyzického kontaktu. Obecně se v př́ípadě osobních dilemat běžní jedinci zdráhají zvolit utilitaristické řešení, které preferuje obětování jedince ve prospěch druhých. Naproti tomu u neosobních dilemat, která pracují s ublížením na delší vzdálenost a bez použití fyzického kontaktu s obětí, volí utilitaristické řešení bez větších potíží (viz např. Greene et al., 2001; 2004; 2009)

${ }^{14} \mathrm{~V}$ př́ípadě testování morálního soudu měly subjekty odpovědět na otázku ,Is it acceptable ... in order to...?“, kdežto v př́ípadě testování potenciálního jednání byla otázka formulována jako „Would you ... in order to...?“ (Tassy et al. 2013).

${ }^{15}$ Nižší úspěšnost při hodnocení morálních otázek nekoreluje u psychopatů ani tak s jejich afektivní stránkou, ale spíše s nižším inteligenčním kvocientem (Aharoni, Sinnott-Armstrong, \& Kiehl, 2012).

${ }^{16}$ Tento fakt vysvětluje, proč psychopati nemají takový problém volit v případě těžkých morálních dilemat utilitaristické řešení, které může být běžnými jedinci považováno za nemorální. Je ale třeba si uvědomit, že utilitaristický kalkul zisků a ztrát může být $\mathrm{v}$ konečném důsledku tou nejlepší možnou volbou. $Z$ tohoto důvodu mohou být někteří psychopati v určitých situacích či profesích pro společnost nakonec užiteční.
} 


\section{Praktické důsledky}

Je zjevné, že důvod, proč se psychopati dopouštějí jednání, které vede k ublížením druhým, je kromě antisociálních tendencí způsobeno především deficitem v afektivní oblasti, který jim neumožňuje adekvátní vcítění do obětí. ${ }^{17}$ Empatie běžným jedincům zabraňuje v takovém jednání a motivuje je k prosociálnímu chování. Jestliže tedy můžeme o psychopatech tvrdit, že racionálně ví, co je správné, a co nikoliv, ale nejsou k takovému jednání kvůli funkčním deficitům daných mozkových oblastí motivováni, nabízí se nutkavá otázka, nakolik jsou za své jednání odpovědní. Tato otázka je však zároveň poněkud ošemetná - dovedeno do důsledku, každý z nás může tvrdit, že za procesy svého mozku, a tedy své jednání nemůže. Domnívám se proto, že oblast, na kterou bychom se měli zaměřit, není primárně filosofický problém svobodné vưle a s ním související morální odpovědnosti, ale trestněprávní aspekt psychopatie.

Psychopatie bývá u jedinců nejčastěji diagnostikována až ve chvíli, kdy se dopustí deliktu a jsou odsouzeni k pobytu za mřížemi. Na rozdíl od nepsychopatických pachatelů je však u nich až čtyřikrát vyšší riziko recidivy, ${ }^{18}$ což svědčí o jejich oslabené motivaci a s ní spojených mizivých šancí na nápravu. V roce 2015 byla v České republice míra recidivy již dříve vězněných pachatelů 66 \%, o dva roky dříve dokonce 71 \% (Rozum, Tomášek, Vlach, \& Háková, 2016). Data pro české prostředí neexistují, nicméně uvádí se, že psychopati tvoří přibližně $1 \% \mathrm{z}$ celkové populace, ale 15 až 25 \% z populace vězeňské (Hare, 1996). Ohodnocení charakterového profilu těchto osob na základě Harova dotazníku dokáže v tomto př́ípadě riziko opětovného prohřešku poměrně úspěšně předpovědět (Serin, 1996; Hemphill, Hare, \& Wong, 1998). ${ }^{19} \mathrm{Je}$ proto zarážející, že se s ním v českém prostředí zatím příliš nepracuje. ${ }^{20}$

Možnosti léčby psychopatie jsou zatím velmi omezené, ne-li žádné. Psychopatie jasně koreluje se sníženou šancí na dokončení léčby. Psychopati obecně vykazují neochotu ke změně životního stylu, nenavazují takové pouto s terapeutem jako běžní jedinci a u některých může mít terapie dokonce opačný efekt (Olver, 2016). Některé výzkumy nicméně ukazují, že vhodně zvolená terapie koncipovaná s ohledem na diagnózu a specifický charakterový profil jedince může vést ke snížení násilných tendencí (Reidy, Kearns, \& DeGue, 2013). Proto je nutné mít nástroj pro ohodnocení takových jedinců, aby se dalo předpovídat jejich potenciální riziko pro společnost ve chvíli, kdy budou propuštěni na svobodu, ale také jejich chování prrímo ve vězení. Zdá se, že i přes své nedostatky je Harův dotazník jedním z nejlepších adeptů na tento úkol.

Současné vědecké poznatky mohou ale vést i ke změně trestání psychopatických jedinců. Právní koncepce trestu pracuje zásadním způsobem s odpovědností jedince za vlastní jednání. Je bez debaty, že psychopatičtí násilníci představují pro společnost závažné riziko a je nutné

\footnotetext{
${ }^{17}$ Dalším důvodem, proč se někteří psychopati dostávají do konfliktu se zákonem, může být i jejich leckdy slepá touha po zisku. V případě vidiny finančního zisku jsou totiž i přes př́ítomnost negativních emocí ochotni porušit v podstatě jakékoliv pravidlo, a to i když ví, že bude následovat trest (Glenn et al., 2009; Jones, 2014). Tento problém se týká i úspěšných psychopatů, kteří mohou především v oblasti finančnictví představovat i přes své kouzlo skutečné riziko (Stevens, Deuling, \& Armenakis, 2012).

${ }^{18}$ Hemphill, Hare a Wong (1998) uvádějí trojnásobnou pravděpodobnost recidivy u nenásilných činů a čtyřnásobnou pravděpodobnost u násilných činů. V případě násilných činů se recidiva týká více než 80 \% pachatelů.

${ }^{19}$ Pro přehled dalších nástrojů k ohodnocení odsouzených viz Blatníková (2016).

${ }^{20}$ Překlad Harova dotazníků do češtiny a jeho následnou aplikaci provedla pro účely své diplomové práce Silvie Johanidesová (Johanidesová, 2007). Oficiální česká verze, jejímiž autory jsou Radek Ptáček, Hana Kuželová, Michaela Borovanská a Adéla Rudá, vyšla v roce 2014 (Hare, 2014). Za zmínku stojí také diplomová práce Veroniky Daňkové zaměřující se na odsouzené ve Věznici Všehrdy, která s touto verzí pracuje (Daňková, 2018).
} 
ji před nimi chránit. S ohledem na jejich omezenou schopnost empatie, antisociální tendence a chybějící motivaci ke změně chování je ovšem otázkou, zda se v jejich př́ípadě nedá skutečně hovořit o omezené odpovědnosti za vlastní jednání (Aharoni et al., 2012; Levy, 2007). Adekvátní psychologické ohodnocení doplněné v budoucnu ideálně i o neurální vyšetření (Häkkänen-Nyholm \& Nyholm, 2012) může velmi pomoci tyto jedince detekovat a určit jejich další osud. Je opodstatněné tvrdit, že věznění zamýšlené jako forma trestu u těchto jedinců vzhledem k jejich časté recidivě selhává. Primárním cílem by tedy neměla být odplata za psychopatovo jednání, ale ochrana společnosti před ním - at’ už se jedná o samostatná zařízení s odpovídajícím typem terapie (srov. Häkkänen-Nyholm \& Nyholm, 2012; Raine \& Glenn, 2014a), nebo alespoň zvláštní vězeňské jednotky oddělující psychopatické a nepsychopatické pachatele, v nichž budou monitorováni. ${ }^{21}$ Ze všech výše uvedených důvodů je proto třeba s konstruktem psychopatie jako nepejorativním pojmem v českém prostředí pracovat a věnovat psychopatickým jedincům pozornost jak v rámci výzkumu, tak praxe.

\section{Grantová podpora}

Př́spěvek vznikl za podpory MŠMT ČR udělené UP v Olomouci (IGA_FF_2019_018). Za nahlédnutí do problematiky psychopatie v českém prostředi děkuji Jaromíru Škodovi.

\section{Reference}

Aharoni, E., Sinnott-Armstrong, W., \& Kiehl, K. (2012). Can Psychopathic Offenders Discern Moral Wrongs? A New Look at the Moral/Conventional Distinction. Journal of Abnormal Psychology, 121(2), 484-497. https://doi.org/10.1037/a0024796

Anderson, N. E., \& Kiehl, K. (2014). Psychopathy: Developmental Perspectives and their Implications for Treatment. Restorative Neurology and Neuroscience, 32(1), 103-117. https:// doi.org/10.3233/RNN-139001

Bartels, D. M., \& Pizarro, D. A. (2011). The Mismeasure of Morals: Antisocial Personality Traits Predict Utilitarian Responses to Moral Dilemmas. Cognition, 121(1), 154-161. https:// doi.org/10.1016/j.cognition.2011.05.010

Bedke, M. S. (2009). Moral Judgment Purposivism: Saving Internalism from Amoralism. Philosophical Studies, 144(2), 189-209. https://doi.org/10.1007/s11098-008-9205-5

Blair, J. (1995). A Cognitive Developmental Approach to Morality: Investigating the Psychopath. Cognition, 57(1), 1-29. https://doi.org/10.1016/0010-0277(95)00676-P

Blair, J. (1997). Affect and the Moral-Conventional Distinction. Journal of Moral Education, 26(2), 187-196. https://doi.org/10.1080/0305724970260206

Blair, J., Jones, F. J., Clark, F., \& Smith, M. (1995). Is the Psychopath 'morally insane'? Personality and Individual Differences, 19(5), 741-752. https://doi.org/10.1016/0191-8869(95)00087-M

Blair, J., \& White, S. F. (2013). Social Cognition in Individuals with Psychopathic Tendencies. In S. Baron-Cohen, M. Lombardo, \& H. Tager-Flusberg (eds.) Understanding Other Minds:

\footnotetext{
${ }^{21}$ Podobná zařízení jsou v České republice zatím dvě - Vazební věznice a Ústav pro výkon zabezpečovací detence Brno a Věznice a ústav pro výkon zabezpečovací detence Opava.
} 
Perspectives from Developmental Social Neuroscience (s. 364-379). Oxford: Oxford University Press.

Blatníková, Š. (2016). Nebezpečnost a násili ve vězenském prostředí. Praha: Institut pro kriminologii a sociální prevenci.

Ciaramelli, E., Muccioli, M., Làdavas, E., \& Pellegrino, G. (2007). Selective Deficit in Personal Moral Judgment Following Damage to Ventromedial Prefrontal Cortex. Social Cognitive and Affective Neuroscience, 2(2), 84-92. https://doi.org/10.1093/scan/nsm001

Cima, M., Tonnaer, F., \& Hauser, M. D. (2010). Psychopaths Know Right from Wrong but Don't Care. Social Cognitive and Affective Neuroscience, 5(1), 59-67. https://doi.org/10.1093/ scan/nsp051

Cooke, D. J., \& Michie, Ch. (2001). Refining the Construct of Psychopathy: Towards a Hierarchical Model. Psychological Assessment, 13(2), 171-188. https://doi.org/10.1037/10403590.13.2.171

Daňková, V. (2018). Porovnání osobnostních charakteristik u osob vykonávajících trest odnětí svobody v rámci vybraných psychodiagnostických metod (Nepublikovaná diplomová práce). Olomouc: Univerzita Palackého v Olomouci.

Decety, J. (2010). The Neurodevelopment of Empathy in Humans. Developmental Neuroscience, 32(4), 257-267. https://doi.org/10.1159/000317771

Decety, J. (2012). The Contribution of Emotion and Cognition to Moral Sensitivity: A Neurodevelopmental Study. Cerebral Cortex 22(1), 209-220. https://doi.org/10.1093/cercor/bhr111

Decety, J. (2014). The Neuroevolution of Empathy and Caring for Others: Why It Matters for Morality. In J. Decety, \& Y. Christen (eds.) New Frontiers in Social Neuroscience (s. 127-151). London: Springer.

Decety, J., Chen, Ch., Harenski, C., \& Kiehl, K. A. (2013). An fMRI Study of Affective Perspective Taking in Individuals with Psychopathy: Imagining Another in Pain Does Not Evoke Empathy. Frontiers in Human Neuroscience, 7(489), 1-12. https://doi.org/10.3389/ fnhum.2013.00489

Decety, J., Michalska, K. J., \& Kinzler, K. D. (2011). The Developmental Neuroscience of Moral Sensitivity. Emotion Review, 3(3), 305-307. https://doi.org/10.1177/1754073911402373

Dutton, K. (2013). Moudrost psychopatů. Brno: Emitos.

Farrington, D. P. (2005). The Importance of Child and Adolescent Psychopathy. Journal of Abnormal Child Psychology, 33(4), 489-497. https://doi.org/10.1007/s10802-005-5729-8

Forouzan, E., \& Cooke, D. J. (2005). Figuring Out la femme fatale: Conceptual and Assessment Issues Concerning Psychopathy in Females. Behavioral Sciences \& the Law, 23(6), 765-778. https://doi.org/10.1002/bsl.669

Glenn, A. L., Iyer, R., Graham, J., Koleva, S., \& Haidt, J. (2009). Are All Types of Morality Compromised in Psychopathy? Journal of Personality Disorders, 23(4), 384-398. https:// doi.org/10.1521/pedi.2009.23.4.384

Glenn, A. L., Kurzban, R., \& Raine, A. (2011). Evolutionary Theory and Psychopathy. Aggression and Violent Behavior, 16(5), 371-380. https://doi.org/10.1016/j.avb.2011.03.009

Glenn, A. L., Raine, A., Schug, R. A., Young, L. \& Hauser, M. (2009). Increased DLPFC Activity During Moral Decision-Making in Psychopathy. Molecular Psychiatry, 14(10), 909-911. https://doi.org/10.1038/mp.2009.76 
Greene, J. D., Cushman, F. A., Stewart L. E., Lowenberg, K., Nystrom, L. E., \& Cohen, J. D. (2009). Pushing Moral Buttons: The Interaction between Personal Force and Intention in Moral Judgment. Cognition, 111(3), 364-371. https://doi.org/10.1016/j.cognition.2009.02.001

Greene, J. D., Nystrom, L. E., Engell, A. D., Darley, J. M., \& Cohen, J. D. (2004). The Neural Bases of Cognitive Conflict and Control in Moral Judgment. Neuron, 44(2), 389-400. https://doi.org/10.1016/j.neuron.2004.09.027

Greene, J. D., Sommerville, R. B., Nystrom, L. E., Darley, J. M., \& Cohen, J. D. (2001). An fMRI Investigation of Emotional Engagement in Moral Judgment. Science, 293(5537), 2105-2108. https://doi.org/10.1126/science.1062872

Häkkänen-Nyholm, H., \& Jan-Olof Nyholm, J. (Ed.). (2012). Psychopathy and Law: A Practitioner's Guide. Malden, MA: Wiley.

Hare, R. D. (1996). Psychopathy: A Clinical Construct Whose Time Has Come. Criminal Justice and Behavior, 23(1), 25-54. https://doi.org/10.1177/0093854896023001004

Hare, R. D. (2003). Hare Psychopathy Checklist-Revised (PCL-R) ( $2^{\text {nd }}$ Edition). Toronto, ON: Multi-Health Systems.

Hare, R. D. (2014). Hareho škála psychopatie - PCL-R, 2. vydání. Praha: Hogrefe-Testcentrum.

Hare, R. D., \& Gust, M. (2015). Bez svědomí: znepokojivý svět psychopatů mezi námi. Praha: Dům Harfa.

Hare, R. D., Hart, S. D., \& Harpur T. J. (1991). Psychopathy and the DSM-IV Criteria for Antisocial Personality Disorder. Journal of Abnormal Psychology, 100(3), 391-398. https://doi. org/10.1037//0021-843x.100.3.391

Hare, D. R., \& Neumann C. S. (2006). The PCL-R Assessment of Psychopathy: Development, Structural Properties, and New Directions. In Ch. J. Patrick (ed.), Handbook of Psychopathy, (s. 58-88). New York: Guilford Press.

Hemphill, James F., Robert D. Hare, \& Stephen Wong. (1998). Psychopathy and Recidivism: A Review. Legal and Criminological Psychology, 3(1), 139-170. https://doi. org/10.1111/j.2044-8333.1998.tb00355.x

Honzák, R., \& Honzák, F. (2018). Čas psychopatů. Praha: Galén.

Johanidesová, S. (2007). Ověrení použitelnosti diagnostické metody Hare Psychopathy Checklist. Př́spěvek k typologii odsouzených (Nepublikovaná diplomová práce). Praha: Univerzita Karlova v Praze.

Jonason, P. K., \& Krause, L. (2013). The Emotional Deficits Associated with the Dark Triad Traits: Cognitive Empathy, Affective Empathy, and Alexithymia. Personality and Individual Differences, 55(5), 532-537. https://doi.org/10.1016/j.paid.2013.04.027

Jones, D. N. (2014). Risk in the Face of Retribution: Psychopathic Individuals Persist in Financial Misbehavior among the Dark Triad. Personality and Individual Differences, 67, 109-113. https://doi.org/10.1016/j.paid.2014. 01. 030

Kelly, D., Stich, S., Haley, K. J., Eng, S. J., \& Fessler, D. M. T. (2007). Harm, Affect, and the Moral/Conventional Distinction. Mind \& Language, 22(2), 117-131. https://doi. org/10.1111/j.1468-0017.2007.00302.x

Klimecki, O., \& Singer, T. (2013). Empathy from the Perspective of Social Neuroscience. In J. Armony, \& P. Vuilleumier (eds.), The Cambridge Handbook of Human Affective Neuroscience (s. 533-549). Cambridge: Cambridge University Press. 
Koenigs, M., Kruepke, M., Zeier, J., \& Newman J. P. (2012). Utilitarian Moral Judgment in Psychopathy. Social Cognitive and Affective Neuroscience, 7(6), 708-714. https://doi. org/10.1093/scan/nsr048

Kopp, C. B., \& Neufeld, S. J. (2003). Emotional Development During Infancy. In R. J. Davidson, K. R. Scherer, \& H. H. Goldsmith (eds.), Handbook of Affective Sciences (s. 347-374). Series in Affective Science. New York: Oxford University Press.

Koukolík, F. (2016). Rozhodování: eseje. Praha: Univerzita Karlova v Praze, Karolinum.

Koukolík, F., \& Drtilová, J. (2006). Vzpoura deprivanti̊: nestviory, nástroje, obrana. Praha: Galén.

Krrížová, I. (2016). Bez svědomí: Znepokojivý svět psychopatů mezi námi (recenze). E-psychologie, 10(1), 77-79.

Lamm, C., Batson, C. D., \& Decety, J. (2007). The Neural Substrate of Human Empathy: Effects of Perspective-Taking and Cognitive Appraisal. Journal of Cognitive Neuroscience, 19, (1), 42-58. https://doi.org/10.1162/jocn.2007.19.1.42

Levy, N. (2007). The Responsibility of the Psychopath Revisited. Philosophy, Psychiatry, and Psychology, 14(2), 129-138. https://doi.org/10.1353/ppp.0.0003

Lilienfeld, S. O., Waldman, I. D., Landfield, K., Watts, A. L., Rubenzer, S., \& Faschingbauer, T. R. (2012). Fearless Dominance and the U.S. Presidency: Implications of Psychopathic Personality Traits for Successful and Unsuccessful Political Leadership. Journal of Personality and Social Psychology, 103(3), 489-505. https://doi.org/10.1037/a0029392

Logan, C., \& Weizmann-Henelius, G. (2012). Psychopathy in Women: Presentation, Assessment, and Management. In H. Häkkänen-Nyholm \& J. Nyholm (eds.), Psychopathy and Law: A Practitioner's Guide (s. 99-125). Oxford: Wiley-Blackwell.

McNab, A., \& Dutton, K. (2015). Psychopatiov průvodce na cestě k úspěchu. Brno: Emitos.

Mikoška, P., \& Novák, L. (2017). Jak současná věda objevuje empatii: Transdisciplinární pohled na klič k lidské duši. Červený Kostelec: Pavel Mervart.

Neumann, C. S., Hare, R. D., \& Newman, J. P. (2007). The Super-Ordinate Nature of the Psychopathy Checklist-Revised. Journal of Personality Disorders, 21(2), 102-117. https://doi. org/10.1521/pedi.2007.21.2.102

Nichols, S. (2002). How Psychopaths Threaten Moral Rationalism: Is It Irrational to Be Amoral? The Monist, 85(2), 285-303. https://doi.org/10.5840/monist200285210

Olver, M. E. (2016). Treatment of Psychopathic Offenders: Evidence, Issues, and Controversies. Journal of Community Safety and Well-Being, 1(3), 75-82. https://doi.org/10.35502/ jeswb. 25

Paulhus, D. L., \& Williams, K. M. (2002). The Dark Triad of Personality: Narcissism, Machiavellianism, and Psychopathy. Journal of Research in Personality, 36(6), 556-563. https:// doi.org/10.1016/S0092-6566(02)00505-6

Raine, A., \& Glenn, A. L. (2014a). Ethical Issues. Psychopathy: An Introduction to Biological Findings and Their Implications, 160-176. New York: New York University Press.

Raine, A. (2014b). Successful Psychopaths. Psychopathy: An Introduction to Biological Findings and Their Implications, 148-59. New York: New York University Press.

Reidy, D. E., Kearns, M. C., \& DeGue, S. (2013). Reducing Psychopathic Violence: A Review of the Treatment Literature. Aggression and violent behavior, 18(5), 527-538. https://doi. org/10.1016/j.avb.2013.07.008 
Rozum, J., Tomášek, J. T., Vlach, J. \& Háková, L. (2016). Efektivita trestní politiky z pohledu recidivy. Praha: Institut pro kriminologii a sociální prevenci.

Serin, R. C. (1996). Violent Recidivism in Criminal Psychopaths. Law and Human Behavior, 20(2), 207-217. https://doi.org/10.1007/BF01065856

Shenhav, A., \& Greene, J. D. (2014). Integrative Moral Judgment: Dissociating the Roles of the Amygdala and Ventromedial Prefrontal Cortex. The Journal of Neuroscience, 34(13), 4741-4749. https://doi.org/10.1523/JNEUROSCI.3390-13.2014

Schramme, T. (2014). Being a (A-)Moral Person and Caring About Morality. In T. Schramme (ed.), Being Amoral: Psychopathy and Moral Incapacity (s. 227-244). London: MIT Press.

Smetana, J. G., Schlagman, N., \& Adams, P. W. (1993). Preschool Children's Judgments about Hypothetical and Actual Transgressions. Child Development, 64(1), 202-214. https://doi. org/10.1111/j.1467-8624.1993.tb02904.x

Stevens, G. W., Deuling, J. K., \& Armenakis, A. A. (2012). Successful Psychopaths: Are They Unethical Decision-Makers and Why? Journal of Business Ethics, 105(2), 139-149. https:// doi.org/10.1007/s10551-011-0963-1

Tabak, B.A., Meyer, M. L, Castle, E., Dutcher, J. M., Irwin, M. R., Han... Eisenberger, I. (2015). Vasopressin, but Not Oxytocin, Increases Empathic Concern Among Individuals Who Received Higher Levels of Paternal Warmth: A Randomized Controlled Trial. Psychoneuroendocrinology, 51, 253-261. https://doi.org/10.1016/j.psyneuen.2014.10.006

Tassy, S., Deruelle, Ch., Mancini, J., Leistedt, S., \& Wicker, B. (2013). High Levels of Psychopathic Traits Alters Moral Choice but Not Moral Judgment. Frontiers in Human Neuroscience, 7(229), 1-6. https://doi.org/10.3389/fnhum.2013.00229

Vignemont, F., \& Singer, T. (2006). The Empathic Brain: How, When and Why? Trends in Cognitive Sciences, 10(10), 435-441. https://doi.org/10.1016/j.tics.2006.08.008

Wynn, R., Høiseth, M. H., \& Pettersen, G. (2012). Psychopathy in Women: Theoretical and Clinical Perspectives. International Journal of Women's Health, 4, 257-263. https://doi. org/10.2147/IJWH.S25518

Yang, Y., Raine, A., Colletti, P., Toga, A. W., \& Narr, K. (2010). Morphological Alterations in the Prefrontal Cortex and the Amygdala in Unsuccessful Psychopaths. Journal of abnormal psychology, 119(3), 546-554. https://doi.org/10.1037/a0019611.

Yoder, J. K., Harenski, C., Kiehl, K. A., \& Decety, J. (2015). Neural Networks Underlying Implicit and Explicit Moral Evaluations in Psychopathy. Translational Psychiatry, 5(8), 1-8. https://doi.org/10.1038/tp.2015.117

Chudárková, P. (2019). Psychopatie, empatie a morálka. Psychologie a jeji kontexty, 10(2), 3-17.

https://doi.org/10.15452/PsyX.2019.10.0009 